\title{
QUALITY ASSESSMENT OF WIDAL TEST IN MICROBIOLOGY LABORATORIES AT PRIMARY AND SECONDARY LEVEL BEFORE AND AFTER IMPLEMENTATION OF STANDARD OPERATING PROCEDURE (SOP): A COMPARATIVE STUDY
}

\begin{abstract}
KHATUN K ${ }^{1}$, MUAZZAM N², SHAMSUZZAMAN SM ${ }^{3}, \mathrm{KAMAL} \mathrm{AHMM}^{4}$, ISLAM MS 5
Abstract

Context: The use of standard operating procedures (SOP) in laboratory testing is one of the most crucial factors in achieving the quality. In primary and secondary level laboratory, the scope for microbiological test is limited. Enteric fever is one of the major public health problem in the developing countries, including Bangladesh. An undiagnosed and maltreated case of enteric fever may result in serious complication and even prove fatal. Widal test is the very extensively used serological test in laboratory at all level to aid in the diagnosis of enteric fever. It is the only available practical test for demonstrating antibodies to Salmonella typhi and S. paratyphi. In this study, an attempt has been made to evaluate the present status of microbiology laboratory by comparing the test results of investigator with that of laboratory staff for widal test at primary and secondary level before and after implementation of standard operating procedure (SOP) .
\end{abstract}

Methods: The present study was performed on clinically suspected cases of enteric fever attending at the primary and secondary level laboratories for widal test. A 120 blood samples were collected before implementing SOP and 50 blood samples were collected and tested after following SOP. A cross sectional, descriptive type of study was conducted in Narsingdi Sador Hospital as secondary level microbiology laboratory and Polash Upzilla Health Complex as primary level microbiology laboratory

Results: Before standard operating procedures (SOP), significant titre of widal test was found more by the investigator than the staff at both primary and secondary level. This difference in results was statistically significant $(p<0.05)$. After SOP difference in the results of significant titre of widal test between investigator and staff was not statistically significant $(p>0.05)$.

Conclusion: Implementing SOP for widal test and after practicing appropriate and standard techniques for dilution of serum at primary and secondary level, discrepancy in the results of widal test between investigator and staff was reduced and overall quality of tests were improved.

Key words : Standard operating procedures (SOP), widal test, enteric fever, quality assesment.

J Dhaka Med Coll. 2014; 23(2) : 227-233.

\section{Introduction :}

The microbiological test procedures should be incorporated in the standard operating procedure (SOP) to promote safe laboratory practice and to generate reliable, reproducible, and rapid laboratory result ${ }^{1}$. A standard operating procedure is a set of written instructions that document a routine and repetitive activity and describe both technical and administrative as well as operational elements of an organization ${ }^{2}$. The use of standard operating procedures (SOP) in laboratory testing is one of the most crucial factor in achieving the quality ${ }^{3}$. There are several components of a quality system. They should all be in place and operating before the end product of good quality laboratory report is likely to be achieved. Paying excessive

1. Dr. Khadeza Khatun, Lecturer, Department of Microbiology . Dhaka Medical College, Dhaka.

2. Dr. Naima Muazzam, Ex-Professor and Head, Department of Microbiology, Dhaka Medical College , Dhaka.

3. Dr. S. M. Shamsuzzaman, Professor, Department of Microbiology, Dhaka Medical College, Dhaka.

4. Dr. A. H. M. Mostafa Kamal, Assistant Professor, Department of Anatomy. Dhaka Medical College, Dhaka.

5. Dr. Mohammad Shaiful Islam, Medical Officer, Medicine OPD, Dhaka Medical College Hospital, Dhaka.

Correspondence: Dr. Khadeza Khatun, Lecturer, Department of Microbiology, Dhaka Medical College, Dhaka, Cell Phone: +8801742618959, E-mail: khadizakamal@yahoo.com 
attention to any one of the component while neglecting others will not achieve improvement in quality ${ }^{4}$.

In primary and secondary level laboratory, the scope for microbiological test is limited but routine microscopic examination of urine, stool, malarial parasite in PBF, Gram staining, Ziehl-Neelsen staining of sputum and some serological tests (widal test, ASO titre etc.) are done almost in every laboratories at primary and secondary leve $1^{5}$. The tertiary level laboratory must carry out the full range of tests required for the curative, preventive and promotive health needs of the community ${ }^{3}$. These tests depend largely on the skill and expertise of the staff and to control the quality of the output, every laboratory must follow the standard operating procedure manuals (SOPMS) in laboratory testing ${ }^{1}$.

Enteric fever refers to either typhoid or paratyphoid fever ${ }^{6}$. It is one of the major public health problem in the developing countries, including Bangladesh ${ }^{7}$. Current estimate from the WHO suggest that there are 12 to 21 millions of enteric fever each year with 700,000 deaths ${ }^{8}$. An undiagnosed and maltreated case of enteric fever may result in serious complication and even prove fatal ${ }^{6}$. Widal test is the very extensively used serological test in laboratory at all level to aid in the diagnosis of enteric fever. It is the only available practical test for demonstrating antibodies to Salmonella typhi and S. paratyphi $i^{9}$. Demonstration of causative agents in the blood is considered to be the conclusive test in the diagnosis of the disease $^{8,10,11}$.

At present, in Bangladesh, microbiology laboratories at different level usually do not follow any SOP for tests which may be the reasons for variation in test results from laboratories to laboratories for the same test. In this study, an attempt has been made to assess the quality of blood for widal test in some microbiology laboratories at primary and secondary level with the aim to improve the quality of those tests after preparing and implementing SOP for those tests.

\section{Methods:}

Clinically suspected cases of enteric fever attending at the primary and secondary level laboratories were selected for widal test. A 120 blood samples were collected before implementing SOP and 50 blood samples were collected and tested after following SOP. A cross sectional, descriptive type of study was conducted in Narsingdi Sadar Hospital (district hospital), Narsingdi, as secondary level microbiology laboratory and Polash Upzilla Health Complex, Narsingdi, as primary level microbiology laboratory. Widal test was done by rapid slide agglutination test (SAT) by using Murex reagent (Murex Biotech Ltd, UK) and following the instruction of the kits. Patients serum was tested for ' $\mathrm{O}$ ' and ' $\mathrm{H}$ ' antibodies against $S$. typhi and $S$. paratyphi $A, B$. The presence of a visible agglutination was related with the presence of the corresponding antibody concentration in the samples. The test was carried out in slide agglutination card.

\section{A) Sample collection techniques:}

- Blood for widal test was collected from the study population by the investigator by exactly following SOP both at primary and secondary level.

- Then serum was separated and separated serum was used for widal test in the laboratory individually by the laboratory staff and the investigator.

- Reports were kept in record and these were compared to evaluate the test results at both level.

- Then after preparing and implementing a SOP for widal test for two weeks, blood was collected again by the investigator and was examined in the same way and test results were compared to see any improvement in quality of those tests in those laboratories.

B) Preparation and preservation of serum for Widal test ${ }^{12,1}$ :

- Under aseptic precaution, using a 5cc sterile disposable syringe blood was collected in a sterile test tube. 
- The test tube containing blood was allowed to clot. Then the tube was centrifuged at $1500 \mathrm{rpm}$ for 15 minutes and serum was separated.

- Serum was transferred carefully to a clear, small vial.

- After labeling, the serum was stored in refrigerator at $2^{0} \mathrm{c}$ to $8^{0} \mathrm{c}$ for up to 72 hours.

- Serum was preserved in micro tube at $20^{\circ} \mathrm{C}$ until use for maximum six months

- Haemolysed or lipaemic samples were discarded.

\section{C) Procedure of Rapid Slide Titration method $^{4,12}$ :}

1) Using a suitable micropipette, 80, 40, 20, 10 or $5 \mathrm{ml}$ of undiluted serum was taken on to a row of $3 \mathrm{~cm}$ diameter circles on a white tile.

2) The bottles containing $\mathrm{O}$ and $\mathrm{H}$ antigens were shakened well and one drop of the appropriate suspension (S. typhi O/H, S.paratyphi A, B O/H) was added to each serum aliquot.

3) The serum and antigen was mixed by stirrer and was spreaded over the entire area of the circle.

4) The test card was slowly rotated (at $100 \mathrm{rpm}$ ) for 1 minute and observed for any agglutination (clumping) by nacked eye.

\section{D) Possible results:}

Macroscopically the pattern of the agglutination were examined. The results were interpreted according to manufactures instructions as follows:

$20 \mathrm{ml}=1 / 80 ; 10 \mathrm{ml}=1 / 160 ; 05 \mathrm{ml}=1 / 320$ and for higher titres, serum was further diluted by equal volume of normal saline.

\section{E) Interpretation ${ }^{4,13}$ :}

If agglutination was present, the results were interpreted as follows :

- High (e"1:320) or rising titre against O antigen suggested that active infection was present.
- High titre $(\geq 1: 320)$ against $H$ antigen and low titre against $O$ antigen suggested past infection or immunization.

- High titre against $\mathrm{H}$ and $\mathrm{O}$ antigen (e"1:320) was considered as active infection

- If the titre against TO was $\geq 1: 160$, it was considered as significant titre.

- If the titre against $T O \leq 1: 80$, it was considered as negative.

\section{F) Quality control:}

Each run of the tests were validated with a positive control and negative control.

The results of the study were recorded systematically. Data analysis was done by using computer SPSS programme and according to the objective of the study. Results were presented in the forms of tables. The tests of significance were calculated by using $\mathrm{x}^{2} \cdot \mathrm{P}$ value $<0.05$ was taken as minimum level of significance, $\mathrm{P}$ value $<0.001$ was taken as highly significant. This study was approved by the Ethical Review Committee of Dhaka Medical College, Dhaka.

\section{Results}

The results are presented in the following tables:

Table-I shows that before SOP at primary level, the titre of $\mathrm{TO} \geq 1: 160$ was found in $15(25.00 \%)$ cases and $\mathrm{TO} \geq 1: 320$ was found in $8(13.33 \%)$ cases by the investigator. TO $\geq 1: 160$ was found in $13(21.67 \%)$ and TO $\geq 1: 320$ was found in $6(10.00 \%)$ cases by the staff of primary level laboratory. Similarly, significant titre of TH was observed in $21(35.00 \%)$ cases, $\mathrm{AH}$ in $4(6.67 \%)$ and $\mathrm{BH}$ in $1(1.67 \%)$ cases by the investigator. At the secondary level, the titre of TO $\geq 1: 160$ was found in $16(26.67 \%)$ and a titre of TO $\geq 1: 320$ was found in $9(15.00 \%)$ cases by the investigator. $\mathrm{TO} \geq 1: 160$ was found in $14(23.33 \%)$ and $\mathrm{TO} \geq 1: 320$ was found in $6(10.00 \%)$ cases by the staff of secondary level laboratory. Significant titre of TH was observed in $19(31.67 \%)$ cases, $\mathrm{AH}$ in $3(5.00 \%)$ and $\mathrm{BH}$ in $2(3.33 \%)$ cases by the investigator. 
Table - I

Results of the widal agglutination titre by the investigator and the staff of primary and secondary level laboratory before SOP

\begin{tabular}{|c|c|c|c|c|c|}
\hline \multirow{2}{*}{\multicolumn{2}{|c|}{$\begin{array}{l}\text { Widal agglutination } \\
\text { titre }\end{array}$}} & \multicolumn{2}{|c|}{ Primary level $(n=60)$} & \multicolumn{2}{|c|}{ Secondary level $(n=60)$} \\
\hline & & Investigator & Staff & Investigator & Staff \\
\hline \multirow[t]{3}{*}{ TO } & $\leq 1: 80$ & $37(61.67)$ & 41(68.33) & $35(58.33)$ & $40(66.67)$ \\
\hline & $\geq 1: 160$ & $15(25.00)$ & $13(21.67)$ & $16(26.67)$ & $14(23.33)$ \\
\hline & $\geq 1: 320$ & $8(13.33)$ & $6(10.00)$ & $9(15.00)$ & $6(10.00)$ \\
\hline \multirow[t]{3}{*}{$\mathrm{TH}$} & $\leq 1: 80$ & $39(65.00)$ & $43(71.67)$ & 41(68.33) & $46(76.67)$ \\
\hline & $\geq 1: 160$ & $12(20.00)$ & $11(18.33)$ & $11(18.33)$ & $10(16.67)$ \\
\hline & $\geq 1: 320$ & $9(15.00)$ & $6(10.00)$ & $8(13.34)$ & $4(6.66)$ \\
\hline \multirow[t]{3}{*}{$\mathrm{AH}$} & $\leq 1: 80$ & $56(93.33)$ & $57(95.00)$ & $57(95.00)$ & $58(96.67)$ \\
\hline & $\geq 1: 160$ & $3(5.00)$ & $3(5.00)$ & $2(3.33)$ & $2(3.33)$ \\
\hline & $\geq 1: 320$ & $1(1.67)$ & $0(0.00)$ & $1(1.67)$ & $0(0.00)$ \\
\hline \multirow[t]{3}{*}{$\mathrm{BH}$} & $\leq 1: 80$ & $59(93.33)$ & $60(100.00)$ & $58(96.67)$ & $59(98.33)$ \\
\hline & $\geq 1: 160$ & $1(1.67)$ & $0(0.00)$ & $2(3.33)$ & $1(1.67)$ \\
\hline & $\geq 1: 320$ & $0(0.00)$ & $\mathrm{O}(0.00)$ & $\mathrm{O}(0.00)$ & $0(0.00)$ \\
\hline
\end{tabular}

Figures in parentheses represent percentage

Table-II shows that before SOP at primary level, significant titre of TO was found in $23(38.33 \%)$ cases, significant titre of TH was observed in $21(35.00 \%)$ cases, $\mathrm{AH}$ in $4(6.67 \%)$ and $\mathrm{BH}$ in $1(1.67 \%)$ cases by the investigator.
At secondary level, significant titre of TO was found in $25(41.67 \%)$ cases, significant titre of TH was observed in $19(31.67 \%)$ cases, $\mathrm{AH}$ in $3(5.00 \%)$ and $\mathrm{BH}$ in $1(3.33 \%)$ cases by the investigator.

Table - II

Difference in significant titre of widal test with the investigator and the staff of primary and secondary level laboratory before SOP

\begin{tabular}{lcccc}
\hline & \multicolumn{2}{c}{ Primary level } & \multicolumn{2}{c}{ Secondary level } \\
Significant titre & Investigator & Staff & Investigator & Staff \\
\hline TO & $23(38.33)$ & $19(31.67)$ & $25(41.67)$ & $20(33.33)$ \\
TH & $21(35.00)$ & $17(28.33)$ & $19(31.67)$ & $14(23.33)$ \\
AH & $4(6.67)$ & $3(5.00)$ & $3(5.00)$ & $2(3.34)$ \\
BH & $1(1.67)$ & $0(0.00)$ & $2(3.33)$ & $1(1.67)$ \\
\hline
\end{tabular}

Figures in parentheses represent percentage

\section{For primary level}

$\mathrm{X}^{2}$ value

df

$P$ value

230

\section{For Secondary level}

$\begin{array}{ll}\mathrm{X}^{2} \text { value } & 0.176 \\ \mathrm{df} & 1 \\ \mathrm{P} \text { value } & <0.05^{*}\end{array}$


Table - III shows that after SOP at primary level, the titre of TO e"1:160 was found in 11 (44.00\%) and a titre of $\mathrm{TO} \leq 1: 320$ was found in $2(6.00 \%)$ cases by the investigator. While $\mathrm{TO} \geq 1: 160$ was found in $10(40.00 \%)$ and $\mathrm{TO} \geq 1: 320$ was found in $1(4.00 \%)$ cases by the staff of primary level laboratory. Similarly, significant titre of TH was observed in $9(36.00 \%)$ cases, $\mathrm{AH}$ in $1(4.00 \%)$ and $\mathrm{BH}$ in no cases by the investigator. At secondary level, the titre of TO $\geq 1: 160$ was found in $10(40.00 \%)$ and a titre of TO $\geq 1: 320$ was found in $2(8.00 \%)$ cases by the investigator. TO $\geq 1: 160$ was found in 10 $(40.00 \%)$ and $\mathrm{TO} \geq 1: 320$ was found in no case by the staff of secondary level laboratory. Significant titre of TH was observed in 7 $(28.00 \%)$ cases, $\mathrm{AH}$ in no and $\mathrm{BH}$ in $1(4.00 \%)$ cases by the investigator.

Table-III

Results of the widal agglutination titre by the investigator and the staff of primary and secondary level laboratory after implementing SOP

\begin{tabular}{cccccc}
\hline \multirow{2}{*}{ Widal agglutination titre } & \multicolumn{2}{c}{ Primary level $(\mathrm{n}=25)$} & \multicolumn{2}{c}{ Secondary level(n=25) } \\
& & Investigator & Staff & Investigator & Staff \\
\hline TO & $\leq 1: 80$ & $12(48.00)$ & $14(56.00)$ & $13(52.00)$ & $15(60.000$ \\
& $\geq 1: 160$ & $11(44.00)$ & $10(40.00)$ & $10(40.00)$ & $10(40.00)$ \\
& $\geq 1: 320$ & $2(6.00)$ & $1(4.00)$ & $2(8.00)$ & $0(0.00)$ \\
TH & $\leq 1: 80$ & $16(64.00)$ & $16(64.00)$ & $18(72.00)$ & $19(76.00)$ \\
& $\geq 1: 160$ & $7(28.00)$ & $7(28.00)$ & $6(24.00)$ & $6(24.00)$ \\
& $\geq 1: 320$ & $2(8.00)$ & $2(8.00)$ & $1(4.00)$ & $0(0.00)$ \\
$\mathrm{AH}$ & $\leq 1: 80$ & $24(96.00)$ & $24(96.00)$ & $25(100.00)$ & $25(100.00)$ \\
& $\geq 1: 160$ & $1(4.00)$ & $1(4.00)$ & $0(0.00)$ & $0(0.00)$ \\
& $\geq 1: 320$ & $0(0.00)$ & $0(0.00)$ & $0(0.00)$ & $0(0.00)$ \\
$\mathrm{BH}$ & $\leq 1: 80$ & $25(100.00)$ & $25(100.00)$ & $24(96.00)$ & $24(96.00)$ \\
& $\geq 1: 160$ & $0(0.00)$ & $0(0.00)$ & $1(4.00)$ & $1(4.00)$ \\
& $\geq 1: 320$ & $0(0.00)$ & $0(0.00)$ & $0(0.00)$ & $0(0.00)$ \\
\hline
\end{tabular}

Figures in parentheses represent percentage

Table- IV shows that after SOP at primary level, significant titre of TO was found in $13(52.00 \%)$ cases, significant titre of TH was observed in $9(36.00 \%)$ cases, $\mathrm{AH}$ in $1(4.00 \%)$ and $\mathrm{BH}$ in no cases by the investigator. At secondary level, significant titre of TO was found in $12(48.00 \%)$ cases, significant titre of TH was observed in 7 (28.00\%) cases, AH in no case and BH in $1(4.00 \%)$ cases by the investigator. Total number of significant titre was found in $23(92.00 \%)$ by the investigator and in $21(84.00 \%)$ by the staff at primary level. At secondary level, total number of significant titre was found in $20(80.00 \%)$ by the investigator and in $17(68.00 \%)$ by the staff.

\section{Table - IV}

Difference in significant titre of widal test with the investigator and the staff of primary and secondary level laboratory after SOP.

\begin{tabular}{lcccc}
\hline & \multicolumn{2}{c}{ Primary level } & \multicolumn{2}{c}{ Secondary level } \\
Significant titre & Investigator & Staff & Investigator & Staff \\
\hline TO & $13(52.00)$ & $11(44.00)$ & $12(48.00)$ & $10(40.00)$ \\
TH & $9(36.00)$ & $9(36.00)$ & $7(28.00)$ & $6(24.00)$ \\
AH & $1(4.00)$ & $1(4.00)$ & $0(0.00)$ & $0(0.00)$ \\
BH & $0(0.00)$ & $0(0.00)$ & $1(4.00)$ & $1(4.00)$ \\
\hline
\end{tabular}

Figures in parentheses represent percentage

For primary level

$\mathrm{X}^{2}$ value

df

$P$ value
0.076

2

$0.963^{\text {ns }}$

\section{For Secondary level}

$\mathrm{X}^{2}$ value

df

0.016

2

$P$ value $0.992^{\text {ns }}$ 
Table -V

Discrepancy in the results of significant widal agglutination titre before and after implementing SOP by the staff of primary and secondary level laboratory with the investigator.

\begin{tabular}{lcccc}
\hline $\begin{array}{l}\text { Significant titre } \\
\text { of widal test }\end{array}$ & \multicolumn{2}{c}{ Primary level } & \multicolumn{2}{c}{ Secondary level } \\
& $\begin{array}{c}\text { Before SOP } \\
(\mathrm{n}=60)\end{array}$ & $\begin{array}{c}\text { After SOP } \\
(\mathrm{n}=25)\end{array}$ & $\begin{array}{c}\text { Before SOP } \\
(\mathrm{n}=60)\end{array}$ & $\begin{array}{c}\text { After SOP } \\
(\mathrm{n}=25)\end{array}$ \\
\hline Discrepancy & $10(16.67)$ & $2(8.00)$ & $12(20.00)$ & $3(12.00)$ \\
No discrepancy & $50(83.33)$ & $23(92.00)$ & $48(80.00)$ & $22(88.00)$ \\
Total 60(100.00) & $25(100.00)$ & $60(100.00)$ & $25(100.00)$ & \\
\hline
\end{tabular}

Figures in parentheses represent percentage.

\section{For primary level}

$\mathrm{X}^{2}$ value

df

$P$ value
0.495

1

$0.482^{\text {ns }}$

\section{For Secondary level}

$\mathrm{X}^{2}$ value

df

$P$ value
0.324
1
$0.569^{\text {ns }}$

Table-V, shows the difference of widal test results between investigator and staff of primary and secondary level laboratory before and after following SOP. Before SOP, discrepancy of widal agglutination titre was found in $10(16.67 \%)$ cases and no discrepancy was found in $50(83.33 \%)$ cases with that of investigator at primary level. At secondary level, discrepancy of widal agglutination titre was found in $12(20 \%)$ cases and no discrepancy was found in $48(80 \%)$ cases with that of investigator. Discrepancy was reduced to $8 \%$ from $16.67 \%$ at primary level and to $12 \%$ from $20 \%$ at secondary level after following SOP for widal test by the laboratory staffs.

\section{Discussion:}

Before SOP out of 60 samples for widal test, discrepancy was found in $10(16.67 \%)$ cases at primary level and in $12(20.00 \%)$ cases at secondary level. After implementing SOP at primary level, out of 30 samples, significant titre of TO was found in $13(52.00 \%)$ cases by the investigator and in $11(44.00 \%)$ cases by the staff. At secondary level out of 30 samples, discrepancy was found in significant titre of TO in $2(8.00 \%)$ cases and TH in one $(4.00 \%)$ case. After following SOP by the staff, discrepancy was reduced to $8 \%$ from $16.67 \%$ at primary level and to $12 \%$ from $20 \%$ at secondary level laboratory. Before SOP, significant titre of widal test was found more by the investigator than the staff at both primary and secondary level. This difference in results was statistically significant $(p<0.05)$. After SOP difference in the results of significant titre of widal test between investigator and staff was not statistically significant $(p>0.05)$. In both primary and secondary level, discrepancy might be due to the fact that dilution of serum was not done in appropriate and standard method by the staffs, interpretation of widal test was not done in appropriate techniques and absence of direct supervising authority like a qualified microbiologist ${ }^{3}$. It was found that after implementing SOP for widal test and after practicing appropriate and standard techniques for dilution of serum at primary and secondary level, discrepancy in the results of widal test between investigator and staff was reduced and overall quality of tests were improved. Sufficient supply of good quality reagents would also help to reduce discrepancy further.

\section{Conclusion}

The use of standard operating procedure (SOP) as practical guideline in laboratory services, aimed at improving the reliability and efficiency in laboratory testing is the backbone of quality health care delivery at primary and secondary levels. Widal test should be done in proper dilution following SOP and should be correctly interpreted. It was found that at all levels, quality of the tests depend not only on the skill and expertise of the laboratory staff but also on the use of SOP for collection, preservation and processing of the sample 


\section{Acknowledgement}

We would like to pay our gratitude to the authority of Bangladesh Medical Research Council (BMRC), Dhaka, for providing us with the partial grant for the study.

\section{References:}

1. WHO, 2003. Guidelines for peripheral and intermediate laboratories. In: Kumari S, Bhatia $\mathrm{R}$, eds. Quality Assurance in Bacteriology and Immunology, $2^{\text {nd }}$ ed. New Delhi: World Health Organization; 2003: p. 1-174.

2. Arora DR. Quality assurance in microbiology. Indian J Med Microbiol 2004; 22(2): 81-6.

3. WHO, 2000. Quality Asssurance. In : Kumari S, Inchhpujani RL, eds. Guideline on standard operating procedures for microbiology, $2^{\text {nd }}$ ed. New Delhi: World Health Organization; 2000: p.1-179.

4. Cheesbrough M. Summary of the clinical and laboratory features of microorganisms. In: District laboratory practice in tropical countries. Part 2. UK: Cambridge University Press; 2000: p. $157-$ 266.

5. Hoque ABMT, Musa SAJM, Hasal A. Guideline and SOP for Government and Private Laboratories, $1^{\text {st }}$ ed. 2008: p.1-175

6. Keusch GT. Salmonellosis. In: Fauci AS, Braunwald E, Isselbacher KJ, Wilson JO, Martin JB, Kasper DL, et al. eds. Harrison's Principles of Internal Medicine. $14^{\text {th }}$ ed. New York: McGrawHill; 1998: p.951-3

7. Sen S, Goyal RS, Dev R. Ciprofloxacin in the management of multidrug resistant typhoid fever. Indian J Paed 1991; 28: 417-9.

8. Forsyth JRL. Typhoid and paratyphoid. In: Collies L, Balows A and Sussman M, eds. Topley and Wilson's microbiology and microbial infections. $9^{\text {th }}$ ed. London: Arnold; 1998: p.459-74.

9. Quiroga T, Goycoolea M, Tagle R, Gonzalez F, Rodriguez L, Villiamoel L. Diagnosis of typhoid fever by two serological methods. Diagnostic Microbiol Infect Dis 1992; 15: 651-6.

10. Mishra M, Thakar YS, Cttande C, Tanshiwale NS, Saojl AM. Rapid detection of enertic fever by coagglutination and counter immunoelectrophoresis. Indian J Pathol Microbiol 1998; 41: 391-6.

11. Asna SMZH, Hussain MA. Blood culture by conventional method: study of 1000 cases. Bangladesh J Pathol 2000; 15(1): 3-6.

12. Collee JG, Marr W. Specimen collection, culture containers and media In: Collee JG, Fraser AG, Marmion BP, Simmons A, eds. Mackie \& McCartney practical medical microbioloy. $14^{\text {th }}$ ed. New York: Churchill Livingstone; 1996: p.95-130.

13. Brooks GF, Butel JS, Morse SA. Enteric Gram Negative Rods. In: Jawetz, Mclnick and Adelberg's medical microbiology. $23^{\text {rd }}$ ed. New York: McGraw-Hill; 2004: p.703-31. 